TITLE:

\title{
Magnetoencephalography with temporal spread imaging to visualize propagation of epileptic activity(Abstract_要旨 )
}

$\operatorname{AUTHOR}(\mathrm{S})$ :

Shibata, Sumiya

\section{CITATION:}

Shibata, Sumiya. Magnetoencephalography with temporal spread imaging to visualize propagation of epileptic activity. 京都大学, 2017, 博士(医学)

\section{ISSUE DATE:}

2017-07-24

URL:

https://doi.org/10.14989/doctor.k20610

\section{RIGHT:}

Final publication is available at

https://www.journals.elsevier.com/clinical-neurophysiology.;

"Magnetoencephalography With Temporal Spread Imaging to Visualize

Propagation of Epileptic Activity". S Shibata et al. (Clin Neurophysiol

128 (5), 734-743. 2017 Jan 30). DOI: 10.1016/j.clinph.2017.01.010 


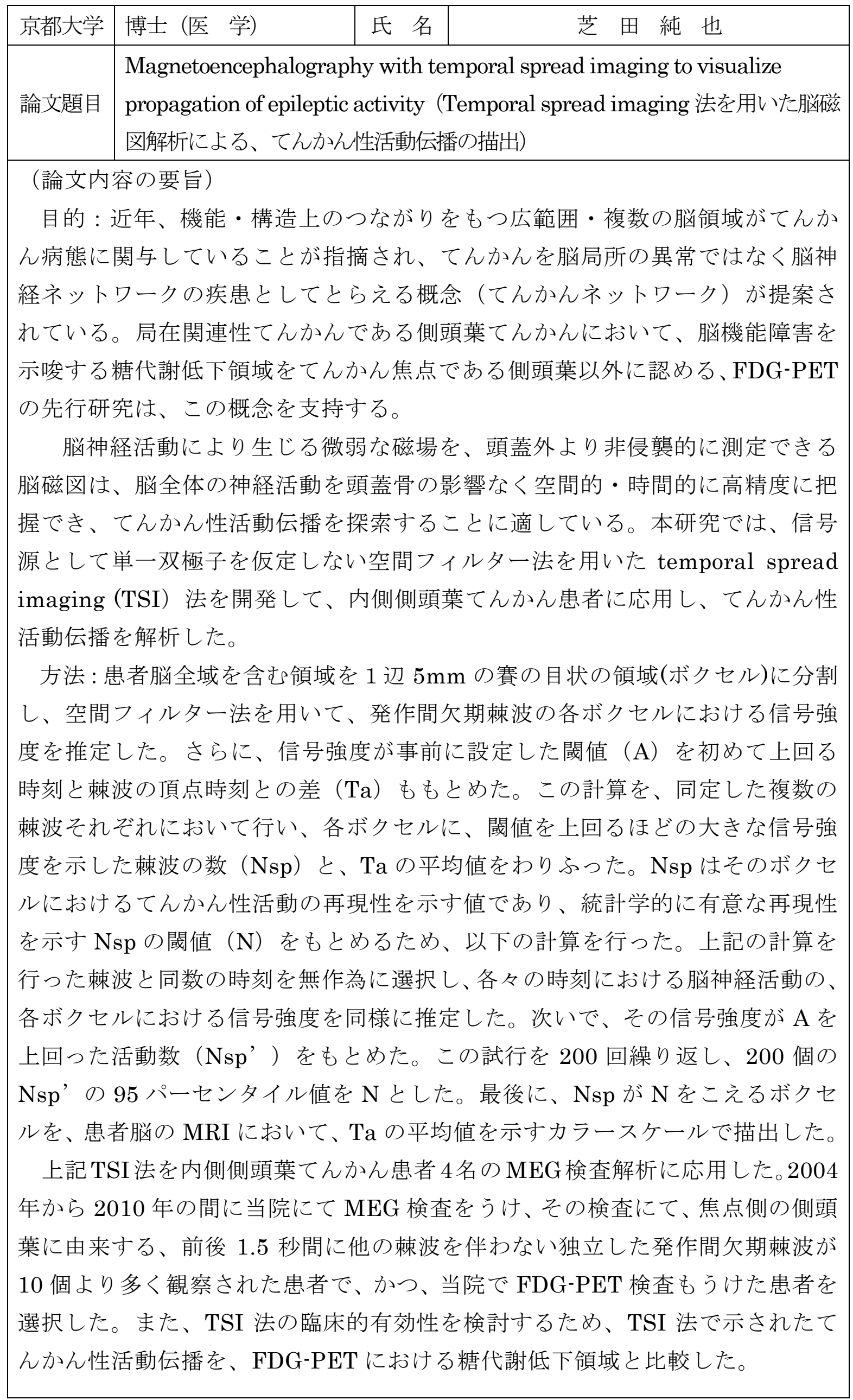

結果：TSI 法により、統計学的に有意な再現性をもって、てんかん性活動を 示した領域が、その活動が生じた時間を示すカラースケールで、MRI 上に示さ れた。臨床応用された 4 名の患者全てで、てんかん性活動が焦点側の側頭葉を こえて伝播しており、そのうちの 3 名では、同側の前頭葉腹外側部に伝播して いることが確認された。その 3 名の FDG-PET では、同側の前頭葉腹外側部に 糖代謝低下領域がみとめられ、TSI 法で示された伝播領域と部分的に一致する ことが示された。

結論 : TSI 法は、てんかん性活動の空間的・時間的広がりを描出し、活動の 再現性を統計学的に評価することを可能にする。本手法で示された電気生理学 的なてんかん性活動の伝播領域が、FDG-PET で示された脳代謝異常領域と一 致したことは、TSI 法がてんかんネットワークの臨床的な解明に有効であるこ とを示唆する。TSI 法を用いた脳磁図解析は、非侵襲的にてんかんネットワー クを可視化できると期待される。

\section{（論文審査の結果の要旨）}

てんかんを脸神経ネットワークの疾患としてとらえる概念（てんかんネット ワーク）が提案されている。先行研究で、糖代謝低下領域がてんかん焦点周囲 以外に示された結果は、この概念を支持する。本論文の目的は、脳磁図を用い て短時間のてんかん性活動伝播の解析手法を確立することである。

脳磁図は、脳神経活動による磁場を頭蓋外より測定し、脳全体の神経活動を 空間的・時間的に高解像度に把握できる。Temporal spread imaging (TSI)法は、 てんかんの信号源を脳磁図で同定するために近年開発された解析法で、信号源 として単一双極子を仮定しない空間フィルター法を用いている。本論文は、TSI 法を発展させ、統計学的に有意な再現性をもっててんかん性活動を示した領域 を、その活動が生じた時間を示すカラースケールで、患者個人の MRI 上に示す ことができるようにした。この新しい TSI 法を内側側頭葉てんかん患者 4 名に 応用し、全ての患者で、てんかん性活動が焦点側の側頭葉をこえて伝播し、そ のうちの 3 名では、同側の前頭葉腹外側部に伝播していることを確認した。ま た、その 3 名で、同側の前頭葉腹外側部に糖代謝低下領域を認め、TSI 法で示 された伝播領域と部分的に一致することを示した。

以上の研究は、てんかんネットワークの解析手法の開発に貢献し、てんかん 病態の解明に寄与寸るところが多い。

したがって、本論文は博士（医学）の学位論文として価値あるものと認める。 なお、本学位授与申請者は、平成 29 年 4 月 17 日実施の論文内容とそれに関 連した試問を受け、合格と認められたものである。

要旨公開可能日： 年 月 日 以降

